\title{
Patterns of long-term survival following Ipilimumab (Ipi): the Memorial Sloan Kettering Cancer Center 10-year metastatic melanoma (MM) experience
}

\author{
David B Page ${ }^{1 *}$, Jarushka Naidoo ${ }^{1}$, Parisa Momtaz', Kita Bogatch', Deborah Kuk', Katherine Panageas', \\ Jianda Yuan', Jedd D Wolchok', Michael Postow ${ }^{1}$
}

From Society for Immunotherapy of Cancer 29th Annual Meeting

National Harbor, MD, USA. 6-9 November 2014

\section{Background}

In two Phase III randomized trials in MM, Ipi improved median overall survival (OS) [1,2]. Here, we evaluate OS and characterize post-Ipi treatment patterns among long-term survivors from a single-institution cohort of patients (pts) treated with Ipi.

\section{Methods}

Through a search of institutional databases, we identified 766 pts with MM treated with Ipi between 1/1/2003 and $12 / 31 / 2013$. As of 4/1/2014, $96 \mathrm{pts}$ have survived $\geq 2 \mathrm{yrs}$, measured from first dose of Ipi. OS was calculated utilizing the Kaplan-Meier method. Disease control was defined as the duration from initiation of Tx until initiation of subsequent systemic Tx or death.

\section{Results}

With a median follow-up of $17 \mathrm{mo}$ (range $0-9 \mathrm{yr}$ ), the median OS for the entire cohort of 766 pts was $15 \mathrm{mo}$, with a 2 -yr OS of $41 \%$. Of the 80 pts with OS $\geq 2$ yrs post-Ipi for whom data are available, $75 \%(\mathrm{n}=60 / 80)$ remain alive and $30 \%(\mathrm{n}=24 / 80)$ remain progression-free following Ipi, with median Ipi disease control of 15mo (range: 3 to 107 +mo). Among pts with progression $(\mathrm{n}=56), 57 \%$ exhibited disseminated progression, $29 \%$ oligometastatic progression, and 15\% CNS-only progression. The most frequent $\mathrm{Tx}$ at first progression was locoregional $(\mathrm{n}=29)$, employed at a median of $11 \mathrm{mo}$ post-Ipi (range: 3 to $55 \mathrm{mo}$ ) and associated with median $15+$ mos disease control

\footnotetext{
${ }^{1}$ Memorial Sloan Kettering Cancer Center, New York, NY, USA
} Full list of author information is available at the end of the article (range 1 to $73+$ mo) (table 1). In pts requiring post-Ipi systemic Tx, long-term disease control was observed across multiple systemic Tx's (table 2).

\section{Conclusion}

Within this single-institution cohort, the median OS and 2 -yr OS were greater than reported previously in Phase III trials $[1,2]$. Potential reasons for this survival advantage

Table 1 Pts receiving locoregional Tx at first progression.

\begin{tabular}{lll}
\hline Locoregional Tx & \# pts & $\begin{array}{l}\text { \# pts achieving } \geq 1 \mathrm{yr} \\
\text { disease control }\end{array}$ \\
\hline CNS, surgery and/or RT & $9 / 80(11 \%)$ & $5 / 9(56 \%)$ \\
Non-CNS, surgery & $11 / 80(14 \%)$ & $8 / 11(73 \%)$ \\
Non-CNS, RT & $6 / 80(8 \%)$ & $3 / 6(50 \%)$ \\
Ablation & $2 / 80(3 \%)$ & $1 / 2(50 \%)$ \\
\hline
\end{tabular}

Table 2 Post-Ipi Systemic Txs.

\begin{tabular}{lll}
\hline $\begin{array}{l}\text { Post-Ipi } \\
\text { Systemic Tx }\end{array}$ & \# pts & $\begin{array}{l}\text { \# pts achieving } \geq 1 \text { yr disease } \\
\text { control* }\end{array}$ \\
\hline $\begin{array}{l}\text { Cytotoxic } \\
\text { Therapy }\end{array}$ & $\begin{array}{l}11 / 80 \\
(14 \%)\end{array}$ & $5 / 10(50 \%)$ \\
Anti-PD-1/PD-L1 & $\begin{array}{l}16 / 80 \\
(20 \%)\end{array}$ & $11 / 15(73 \%)$ \\
BRAF inhibitor & $\begin{array}{l}10 / 80 \\
(13 \%)\end{array}$ & $7 / 9(78 \%)$ \\
Ipi re-induction & $\begin{array}{l}18 / 80 \\
(23 \%)\end{array}$ & $5 / 16(31 \%)$ \\
Other clinical & $13 / 80$ & $1 / 13(8 \%)$ \\
trial & $(16 \%)$ & \\
\hline
\end{tabular}

*pts with ongoing disease control and <1yr follow up excluded 
include: referral bias, heterogeneous Ipi dosing/schedule, and access to subsequent trials (i.e. anti-PD-1/PD-L1, BRAF inhibitor). The majority of long-term survivors required subsequent $\mathrm{Tx}$, however prolonged disease control was achieved with a range of Tx's. Pts who experience oligometastatic/CNS-only progression following Ipi may achieve prolonged disease control with locoregional Tx alone.

\section{Authors' details}

${ }^{1}$ Memorial Sloan Kettering Cancer Center, New York, NY, USA. ${ }^{2}$ Immune

Monitoring Facility, Sloan Kettering Institute, New York, NY, USA.

Published: 6 November 2014

\section{References}

1. Hodi F, O'Day S, McDermott D, et al: Improved Survival with Ipilimumab in patients with metastatic melanoma. N Engl J Med 363:711-23.

2. Robert $C$, Thomas L, Bondarenko I, et al: Ipilimumab plus dacarbazine for previously untreated metastatic melanoma. N Engl J Med 364:2517-26.

doi:10.1186/2051-1426-2-S3-P117

Cite this article as: Page et al:: Patterns of long-term survival following Ipilimumab (Ipi): the Memorial Sloan Kettering Cancer Center 10-year metastatic melanoma (MM) experience. Journal for ImmunoTherapy of Cancer 2014 2(Suppl 3):P117.

Submit your next manuscript to BioMed Central and take full advantage of:

- Convenient online submission

- Thorough peer review

- No space constraints or color figure charges

- Immediate publication on acceptance

- Inclusion in PubMed, CAS, Scopus and Google Scholar

- Research which is freely available for redistribution

Submit your manuscript at www.biomedcentral.com/submit 